\title{
Hypothalamic hormones a.k.a. hypothalamic releasing factors
}

\author{
Roger Guillemin \\ Salk Institute for Biological Studies, 10010 N. Torrey Pines Road, La Jolla, California 92037, USA \\ (Requests for offprints should be addressed to R Guillemin; Email: guillemin@salk.edu)
}

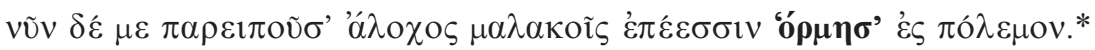

Homer, Epic, Iliad, Book 6 line 337.

\begin{abstract}
Originally searched for and eventually isolated as factors of hypothalamic origin controlling anterior pituitary secretions, these hypophysiotropic peptides are now a chapter of physiology and medical endocrinology of their own. Defying the concept of 'neuropeptides' they and their receptors are now known to be ubiquitous and to have subtle as well as profound effects on a large number of
\end{abstract}

functions of both soma and psyche. This review will be composed of brief essays on current knowledge of each of the original 'hypothalamic hormones', TRH, GnRH, somatostatin, GHRH and corticotropin releasing hormone and will close on possible and probable futures.

Journal of Endocrinology (2005) 184, 11-28

\section{Introduction}

A short history and the tribulations of nomenclature

It was with pleasure that I read and answered Stephen G Hillier's invitation to contribute a review-style article on 'Hypothalamic Releasing Factors' for the Journal's celebration of the introduction of the word 'hormone' by Ernest $\mathrm{H}$ Starling in his 1905 Croonian Lectures (Starling 1905a). Then came a no less gracious letter from Julian Davis with all sorts of practical editing considerations for the writing of a review-style article on 'Releasing Hormones'. I will have more to say on nomenclature below.

The proposal that the brain is somehow involved in controlling pituitary functions goes back to the 1930s - see the 1936 Croonian lecture by F H A Marshall (1936) and the imposing volume 'The Hypothalamus and Control Levels of Autonomic Function' as the proceedings of a symposium organized in New York in 1939 by the Association for Research in Nervous and Mental Diseases (Fulton et al. 1940).

While others were also involved, the major credit for establishing the concept of a hypothalamic neurohumoral control of anterior pituitary secretions must undoubtedly

\footnotetext{
* "Now, however, my wife, persuading me with the right words, urges me to battle."
}

go to Geoffrey W Harris working at the Maudsley Hospital in London in the 1950s, and later as head of the Department of Physiology in Cambridge.

The central proposal of Harris' neurohumoral control of pituitary function was that the unusual capillary system existing between the ventral hypothalamus and the anterior lobe of the pituitary would be the conduit for substances of hypothalamic origin that would act as releasers of each and all pituitary hormones upon reaching the parenchyma of the gland. There were powerful doubters, such as Solly Zuckerman. I will only refer here to the volume written by G W Harris in 1955 for a survey of the literature to that date (Harris 1955).

It was not until 1969 that the concept was finally validated by the isolation and structural characterization of one of these postulated messengers, a totally novel molecule, thyrotropin releasing factor (TRF) in extracts of ventral hypothalamic tissues (Burgus et al. 1969, Nair et al. 1970) and ultimately (ten years later) the actual demonstration and quantitative measurements of several of that (and other) hypothalamic messengers in blood obtained by catheterization of the hypothalamo-pituitary vessels (Wilber \& Porter 1970).

Immunohistochemistry showed the anatomical distribution of the hypothalamic neurones involved in the synthesis and neuro-secretion of these newly discovered substances, a releasing factor for the secretion of 
thyrotropin (TSH) and simultaneously of prolactin (in most species), another for the secretion of both gonadotropins - luteinizing hormone (LH) and follicle stimulating hormone (FSH), another for the secretion of growth hormone $(\mathrm{GH})$, and another for the secretion of adrenocorticotropin (ACTH).

These novel substances of hypothalamic origin came to be referred to as 'releasing factors' (RF) (Saffran \& Schally 1956); hence thyrotropin releasing factor (TRF), luteinizing hormone (gonadotropin) releasing factor (LRF/ GnRF), growth hormone releasing factor (GRF), corticotropin releasing factor (CRF), a nomenclature ('factors') in keeping with the fact that their molecular structure had not been established. When that was achieved, they were then referred to as 'releasing hormones' $(\mathrm{RH})$ or hypothalamic hormones. They certainly fulfilled the definition and use of the word as proposed by E H Starling.

Personally, I am still somewhat partial to the nomenclature 'releasing factors'. Referring to them, as a group or individually, one immediately thinks 'hypothalamopituitary'. Indeed, in the case of 'growth factors' (fibroblast growth factor (FGF), epidermal growth factor (EGF), nerve growth factor (NGF), platelet-derived growth factor (PDGF) ....), we think immediately of a series of substances which no one proposed to call 'growth hormones' when their molecular structures were established. However, with the unexpected observation (Brazeau et al. 1973) and characterization in hypothalamic extracts of an inhibitory factor of the secretion of growth hormone which I named somatostatin we should feel more comfortable with the reference to these 'hypothalamic hormones', well in keeping with the use of the words by Starling who described, indeed, activating and inhibiting effects of his tissue extracts in his 1905 Croonian lecture series. At the end of this review, after the many new facts it will encompass, I will come back to that terminology.

Another example of problems with nomenclature is the now totally accepted use of the word 'agonist' when referring to analogs of $\mathrm{GnRH}$ (see below) which are many times more potent than the native molecule, but are used as inhibitors of the secretion of gonadotropins through mechanisms now well understood and that we will discuss below. But a molecule which is $1 / 100^{\text {th }}$ as active as the native sequence is also an agonist of $\mathrm{GnRH}$. Referring to the analogs which are so much more powerful than the native sequence, the effects observed and desired are actually of receptor down-regulation and inhibition (see below in the section on $\mathrm{GnRH}$ ) leading to decreased function. It would be much more satisfactory to refer to these molecules as 'superagonists', a word I had suggested and used as early as 1978 (with obviously no success) (Rivier et al. 1978), the word to be associated with the ultimate inhibitory activity; just one more example of these vagaries of nomenclature where bad habits are sure to be winners.

Let me close this introduction both to this review and to this field with a short historical recounting. It took from the early 1950s to 1969, manipulating literally several millions of fragments of sheep (in my laboratory) or pig (in Schally's laboratory) hypothalami, from tons of sheep or pig brains (Fig. 1), eventually to recognize, isolate and characterize the first of these hypothalamic hormones, TRF, the thyrotropin releasing factor, isolating less than $1 \mathrm{mg}$ of the substance, and eventually characterizing its molecular structure (in 1969) by early mass spectrometry as that of a (simple!) tripeptide (Fig. 2) (Burgus et al. 1969, Nair et al. 1970). The growth hormone releasing factor (GRF, GHRH) was eventually, 20 years after the demonstration of its existence (Reichlin 1960), isolated and characterized as a 44 residue peptide (Guillemin et al. 1982), not from the hypothalamus, but from a rare tumor of the pancreas which had induced acromegaly in the absence of a pituitary tumor. The substance of (human) hypothalamic origin was shown later to be identical (Bohlen et al. 1983). The corticotropin releasing factor, the existence of which was shown in the early 1950s (Guillemin \& Rosenberg 1955, Saffran \& Schally 1955), was not fully characterized until 1981 (Vale et al. 1981).

For today's practicing biologist this seems hard to believe. None of the early separation methods would work on microgram quantities of extracts, the substances sought could only be recognized in the effluent of these separation methods (ion exchange or paper-chromatography, the various phases of counter-current distribution) by complex and time consuming bioassays, HPLC of (underivatized) native peptides was not available until 1975 with the isolation of $\alpha$-endorphin, and sequencing of somatostatin in 1973 by manual Edman degradation was at the rate of one residue/day. An automated peptide sequencer was available in 1982 for GRF and mass spectrometry was becoming far more available. All of the above is like the archeology of what will follow in this short review. For those of us who were the early plodders of that era, the current state and course of things are as humbling as they are rewarding.

But far more than revolutionary developments in methodology has happened in the 50 years or so since the original isolation and characterization of these hypothalamic molecules. The original hypophysiotropic hypothalamic peptides with which we were dealing have been found to be widely distributed throughout the central nervous system in well-defined locations. Moreover, what we originally recognized as neuropeptides are now known to be expressed and functional in tissues of the gastrointestinal tract, the lungs, the heart, the hematopoietic system, and the immune system. And, more importantly, the same is true of the multiple receptors for these same peptides.

As we will see in the next sections, molecular biology with its powerful methodology has expanded exponentially the original knowledge we referred to above, both for basic research and clinical medicine. A search on the website of the Library of Medicine, Washington, DC, USA 


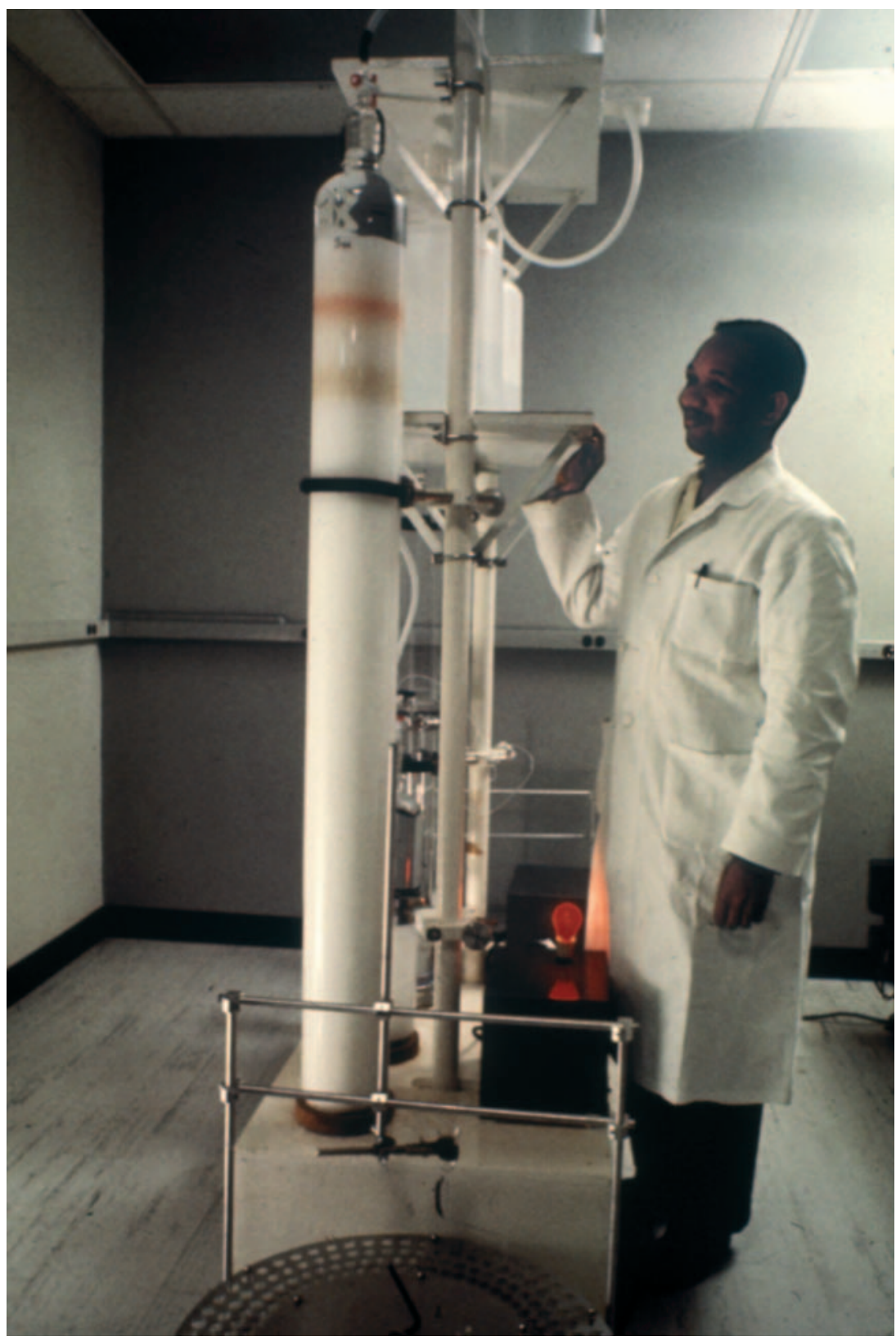

Figure 1 In 1965 at Baylor College of Medicine, Houston, Texas. Our first step of purification on Sephadex G25. The column was $2 \mathrm{~m}$ tall, $0 \cdot 20 \mathrm{~m}$ diameter and loaded with 3.5 kg Sephadex G-25 in dilute acetic acid (Raymond Givens, laboratory assistant next to 'his' column). In a typical run, which would last 24-36 h, we would apply the crude $2 \mathrm{M}$ acetic acid extract of 200-250 000 fragments of sheep hypothalamus. An active fraction (as per bioassays ...) was then processed on several successive steps of counter-current distribution, ion exchange chromatography etc ...., all followed by bioassays. Compare this with today's methodology using PCR or the recently proposed 'peptidomics', isolating and sequencing in a single pass over 100 peptides from one half of one mouse pituitary or a few mgs from any tissue, by combined nanoscale liquid chromatography, electrospray ionization mass spectrometry and fitting with GenBank's EST database. 


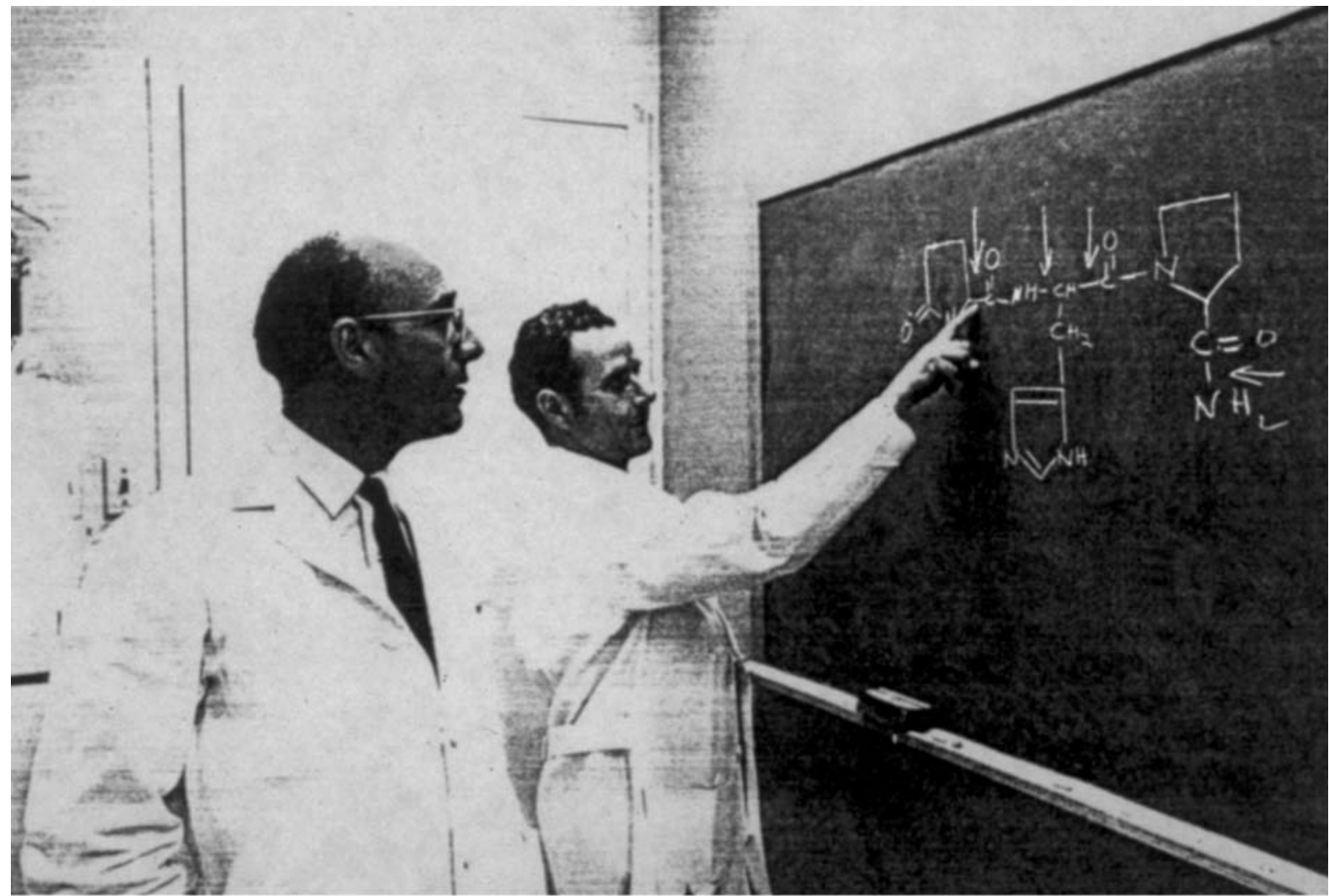

\section{Roger Guillemin Roger Burgus}

\section{first structure of TRF from mass spectrometry 9 June 1969}

Figure 2 First inscription of the structure of TRF by Roger Burgus with locations of fragmentation ions from the early results of mass spectrometry in collaboration with Dominic M Desiderio from the Lipid Research Center, Baylor College of Medicine, Houston, Texas. Roger Burgus died in 1998 after a long illness.

for publications dealing with the original molecules we isolated has yielded well over 100000 references. It is thus quite impossible to produce a complete critical review of that now immense literature within the constraints of this Starling Review, and more importantly because of the very limitations of this reviewer. I will thus limit myself to selected topics/issues which, in my opinion, represent some of the most intriguing observations made over the years in as much as they departed from or expanded the original way of thinking about one or other of these hypothalamic peptides. When a comprehensive review on a particular subject has been written, I will make reference to it and will discuss only recent reports which would have appeared after that review. I am well aware that I will not touch here on all the expanding observations which have been reported in the field, and I do not intend to discuss or describe in detail the methodologies leading to these observations and conclusions.
The sequence of these essays will follow that of the dates (year) on which each of these hypothalamic peptides was originally isolated, characterized, and reported.

\section{TRF, TRH}

A very comprehensive review on TRH, its overall biology, including its non-hypophysiotropic activities, biosynthesis, and biology of non-TRH fragments from the precursor, was published in 1999 (Nillni \& Sevarino 1999).

The small tripeptide, pGlu-His-Pro- $\mathrm{NH}_{2}$, is indeed processed from a larger precursor $(29 \mathrm{kDa}, 255$ residues), through now classic cleavage mechanisms, C-terminal amidation, and cyclization of the N-terminal Gln to pGlu. Pro-TRH mRNA has been located in several brain areas other than the paraventricular nucleus (olfactory bulb, lateral hypothalamic area, median eminence, preoptic area, 
periaqueductal gray, brain stem and dorsal vagal complex) and in non CNS tissues (pancreatic $\beta$-cells where TRF and somatostatins show opposing paracrine effects on glucagon secretion, the whole gastrointestinal tract where TRF may modulate contractions, the genitourinary system, ventral prostate, Leydig cells, epididymis, seminal vesicles). Multiple physiological activities of TRH on the functions of these various organs have been reported. Of early clinical interest was the reported presence of TRH in several locations of the ventral horn of the spinal cord, either in motor neurons or in extensive projections from bulbospinal neurons to motor neurons. TRH enhances motor neuron firing leading to increased muscle tone, contractibility and spinal reflexivity. Clinical studies have repeatedly reported beneficial effects of i.v. administration of TRH in several motor neuron diseases. These improvements, for some unexplained reason, are of short duration (days to weeks) (Brooke 1989).

Some remarkable recent observations have been made that lead one to consider that the hypothalamic TRHsecreting neurons are under multiple controlling mechanisms which all are otherwise involved in the control of appetite regulation, food intake, along with TSH-release and ultimately thyroid function, in some sort of what could be considered as a general regulatory-system determining energy expenditure and adaptive thermogenesis. It has long been known that during starvation in rodents, the pituitary-thyroid axis is down-regulated leading to low levels of circulating TSH and thyroid hormones. Several reports have shown that leptin is involved in regulating release of TRH from a defined population of TRH neurons in the paraventricular nucleus. Low levels of circulating leptin are accompanied by a decrease in TRHmRNA in TRH-secreting neurons; transfection data and in vivo studies show that leptin can regulate TRH gene expression via activation of intracellular signal-transducerand-activator-of transcription 3 (STAT-3) proteins in TRH neurons, with evidence that the STAT-3 binding site on the leptin receptor is also required for the effect on TRH release (Guo et al. 2004, Huo et al. 2004). Moreover, it appears that the leptin-responsive TRH neurons are concentrated in the caudal region of the medial and periventricular parvocellular subnucleus of the paraventricular nucleus (Huo et al. 2004), i.e. only in a subpopulation of the entire nucleus that has been shown to be specifically involved in the hypophysiotropic activity of TSH release leading to thyroid activation. Indeed, leptin does not activate STAT-3 in TRH neurons located in other regions of the hypothalamus, such as the perifornical and lateral hypothalamus (Huo et al. 2004).

The TRH neurons in the paraventricular nucleus have also been shown to express receptors for $\alpha-\mathrm{MSH}$ (melanocortin-4R), a peptide involved in appetite and satiety control, suggesting that both signaling systems may regulate TRH gene expression. In cell cultures the TRH promoter has been shown to respond to both these signaling pathways through STAT-3 and CREB binding sites that mediate leptin and melanocortin responses respectively (Kim et al. 2002, Guo et al. 2004).

Other recent publications are extending the complexity of what appears to be an integrated mechanism controlling/ regulating the overall homeostasis (or should we say allostasis) of energy production and expenditure of the whole organism. All peptides known to be involved in appetite control or response to feeding or fasting are now known to be part of the mechanisms controlling TSH release (galanin (Wittmann et al. 2004b), neuropeptide Y (NPY) (Broberger et al. 1999), $\alpha-\mathrm{MSH}$ (Fekete et al. 2000, Kim et al. 2002), leptin, as already quoted above). There is also recent evidence that catecholamines originating from medullary (C1-3) adrenergic neurons and shown to be co-localized with CART (cocaine-and-amphetamine-regulated-transcript)proteins make multiple connections with the hypophysiotropic TRH neurons in the paraventricular nucleus and are involved in the rapid release of TRH in response to cold exposure (Wittmann et al. 2004a).

All these remarkable observations of functional relationships, combined with morphological demonstrations of co-locations of these peptides and their receptors in specific neurons, are the vindication of the early proposal of the existence of peptidergic neurons first in insects, and later in birds and mammalians by the remarkable morphologist, Berta Scharrer (Fulton et al. 1940, Scharrer 1978).

With the recent demonstration that leptin can directly target the TRH promoter in vivo in neurons of the paraventricular nucleus (Guo et al. 2004) and that it can in vitro promote neurite outgrowth from arcuate neurons in well controlled situations (Bouret et al. 2004, Pinto et al. 2004) with opposite effects of ghrelin (see below), we may begin to understand the role(s) of these peptides in the functioning and the structural evolution and/or maintenance of the neurons in which they co-locate with one of the classic neuromediators.

The rapid inactivation of TRH by plasma and tissue incubates has been extensively studied by several groups (see Bauer (2004) for review). I will only mention the remarkable substrate specificity of an enzyme designated TRH-degrading ectoenzyme (TRH-DE) which selectively inactivates $\mathrm{TRH}$, a unique property among neuropeptide-inactivating enzymes. At the pituitary level, the activities and the mRNA levels of TRH-DE are stringently regulated by thyroid hormones as well as by estradiol, strongly indicating that on adenohypophyseal target sites this enzyme serves regulatory functions for the release of pituitary hormones. In the brain, the activity of TRH-DE is not influenced by peripheral hormones but the high activity of this enzyme and the distinct localization of TRH-DE in relation to the other elements of the TRH-signaling system (Heuer et al. 2000) strongly suggest that this peptidase may act as a terminator of TRH acting in extrahypothalamic brain areas as a neuromodulator and/or neurotransmitter. 


\section{LRF, LHRH, GnRH}

Early isolation and sequencing showed that porcine and ovine LRF (GnRH) have the same decapeptide sequence, including pyro-Glu N-terminal and amidated Gly as C-terminal. Very rapidly it was shown that the molecule was active in all species studied, from mammalians to birds, fish, and amphibians to stimulate release of gonadotropins usually leading to ovulation, egg laying, spawning. In mammalians, including humans, a bolus i.v. injection of the decapeptide released simultaneously LH and FSH. Perfusion of GnRH, however, after an immediate increase in LH and FSH plasma concentration, showed a gradual and persistent fall in LH and FSH secretion that was not explained by depletion of pituitary stores. In a remarkable series of elegant physiological studies in the monkey, Knobil and his collaborators demonstrated that the endogenous hypothalamc release of $\mathrm{GnRH}$ was pulsatile, with a frequency of 60-90 min depending on the animal, each GnRH pulse being correlated with electrical activity of similar frequency in the arcuate nucleus of the hypothalamus, and each GnRH pulse being followed in seconds by secretion of LH measured in the jugular vein or better still in hypophysial superficial veins. In pituitary stalk sectioned animals peripheral intravenous injection of GnRH in a pulsatile pattern would regularly stimulate secretion of LH for any length of time so long as the pulsatile mode was maintained (Knobil \& Hotchkiss 1988).

The question remained as to the controlling origin of the periodic firing of the medial basal hypothalamus neurons releasing $\mathrm{GnRH}$ in the hypothalamo-pituitary vessels. An in vitro perifusion system of human fetal mediobasal hypothalamus (20-23 weeks of gestation) and from adult brains showed that the fragments would release $\mathrm{GnRH}$ in discrete pulses with a periodicity of about 60-100 min. The secretion was $\mathrm{Ca}^{2+}$-dependent and could be suppressed by morphine, an effect that was reversed by naloxone (Rasmussen et al. 1989). But was the $\mathrm{GnRH}$ pulse generated an intrinsic property of the GnRH neurons or was it influenced by other neurons in the surrounding tissue of the medial basal hypothalamus? That question was answered by the development of immortalized GnRH secreting neurons (GT-I neurons) by genetically targeted tumorigenesis (Mellon et al. 1990). These cells express neuronal but not glial cell markers. The GT-I neurons express $\mathrm{GnRH}$ mRNA, release $\mathrm{GnRH}$ in response to depolarization, or spontaneously in a pulsatile manner. They also respond to a series of agents for which they have receptors - estrogens, opiates, $\beta_{1}$-adrenergicand $\mathrm{D}_{1}$-dopaminergic-receptors, tyrosine kinasereceptors, activators including insulin-like growth factor (IGF)-I and -II, FGF2, and insulin. Thus, the GnRH neurons per se appear to constitute the GnRH pulse generator. Probably the most remarkable observation made with the GT-I cells was that they were shown to express a GnRH-receptor the activation of which is associated with rapid and dose-dependent increase in cytoplasmic $\mathrm{Ca}^{2+}$ concentration and $\mathrm{GnRH}$ release, indicating an autocrine regulation of GnRH (Cesnjaj et al. 1993). The firing and release of GnRH by GT-I cells is estrogen sensitive, in keeping with the well-known proestrous surge of gonadotropins.

There is good evidence that GnRH controls activation of the gene expression for the $\alpha$ - and $\beta$-subunits of LH and FSH, dimerization of the $\alpha-\beta$-submits, and glycosylation, in accord with the frequency of the pulse availability of the peptide $(\mathrm{GnRH})$.

In all these studies, FSH, as measured by highly specific immunoassay for the $\beta$-chain (so as to avoid false positives due to the fact that LH and FSH share an identical $\alpha$-chain) would usually accompany LH in its secretory peaks but not always or consistently. Pulse administration of $\mathrm{GnRH}$ with pretreating or acute combined administration of activin, follistatin, with or without $\alpha$-estradiol never consistently produced a pattern of specific, singular secretion of FSH. Electrical stimulation, localized stereotactic lesions of the paraventricular nucleus-dorsal anterior hypothalamus i.e. a region different from the region involved in $\mathrm{GnRH}$ secretion (in rodents, a somewhat loose network referred to as the septo-preoptic-infundibular pathway) (Silverman et al. 1987) have been claimed to modify FSH release without altering LH pulsatility. A report from the laboratory of McCann, who was the first, in 1964, to propose the existence of an FSH-controlling center in the hypothalamus, of a partial purification of an FSH-releasing factor from sheep hypothalamus extracts stopped short of reporting isolation and characterization of such a substance. That was the status until a couple of years ago (Padmanabhan \& McNeilly 2001).

Relatively early after the isolation and sequencing of the porcine and ovine GnRHs, it was realized that the GnRHs isolated from several classes of vertebrates showed multiple substitutions in their sequence when compared with the pig or sheep GnRH. It was also realized that these structural variants of $\mathrm{GnRH}$ were distributed in a wide range of tissues (midbrain, sympathetic ganglia, immune $\mathrm{T}$ and $\mathrm{B}$ lymphocytes, breast and prostate cancers), where they were shown to have specific biological activities in relation to the particular tissues and later were correlated with the presence of $\mathrm{GnRH}$ receptors (see below). In most vertebrate species two or three forms of GnRH could be demonstrated, suggesting early gene duplications.

One of these variants, originally isolated in chicken brain (now referred to as chicken GnRH II or GnRH II) was found to be universally present and totally conserved in all vertebrates from fish to humans (Millar 2003, Neill et al. 2004). GnRH II is widely distributed in tissues suggesting that it has acquired significant functions through the phylogeny. While the genomic and mRNA structures of GnRH I and II are closely related, GnRH II is expressed at much greater levels outside its brain locus, 
particularly in the kidney, bone marrow and prostate, leading one to suggest that the peptide has specific functions in these tissues. Molecular phylogenetic analysis shows that the gene coding for GnRH II is likely the result of a duplication before the appearance of vertebrates and predicts the existence of a third GnRH form in humans and other vertebrates (White et al. 1998). Indeed, a third form, GnRH III was recently characterized in the lamprey and it has been reported by immunofluorescence also to be located in the GnRH neurons of rat and human hypothalamus more particularly involved in the secretion of FSH (Lumpkin et al. 1989, Dees et al. 1999). GnRH III has been proposed ( $\mathrm{Yu}$ et al. 2002) as the long sought FSHRF, but there is no consensus on that proposal (Kovacs et al. 2002). The demonstration of a specific FSH releasing factor is still open.

As I said above the cDNA for the receptor of GnRH II has been cloned in amphibians, its homologs in primates have been sequenced (Millar et al. 2001, Neill et al. 2001), and their locations ascertained, thus leading to an investigation of functions of GnRH II other than hypophysiotropic ones.

The type II receptors have partial identity with the human type I receptor, both having a characteristic G-protein coupled receptor (GPLC) structure though with some differences in the protein C-terminal sequence, suggesting an early evolutionary gene duplication (Millar 2003). GnRH II was found to be about 400 times more potent than GnRH I in binding that receptor. GnRH II has been reported to be present in extracts of amphibian sympathetic ganglia where, like GnRH I, it appears to be involved in synaptic transmission in the sympathetic ganglia via a receptor highly specific for GnRH II. Because the peptide facilitates fast excitatory transmission by neurotransmitters (Bosma et al. 1990), this could represent a general mechanism for GnRH II to function as a neuromodulator in its multiple locations in the nervous system. In many of the CNS areas (midbrain, supraoptic nucleus) both the type II receptor and the peptide GnRH II have been demonstrated in the same neurons, often overlapping with early developing mammalian GnRH I cells, at least in early embryo development. Neurons that express the mammalian gene for GnRH I in the preoptic area and periventricular region of the hypothalamus stained with type II GnRH receptor antiserum (Rhesus monkey), suggesting that GnRH II might regulate mammalian GnRH I neurons (Millar 2003). These multiple examples of the peptide GnRH I and/or II and the GnRH I receptor being present in neurons alongside classic neurotransmitters and being able to facilitate (modulate) synaptic transmission may be another example of what we mentioned earlier regarding leptin and, as we will see below, probably also that regarding CRF and urocortin and glutamatergic transmission.

It would be interesting to see whether GnRH II could stimulate and maintain dendrite growth and structures.
Changes in $\mathrm{GnRH}$ content of brain areas, cell number and cell size in response to visual, olfactory and other stimulants of sexual behavior have been observed in many species from fish to mammals (Rissman et al. 1997).

Neill and collaborators (2004) have recently reported the successful identification of a gene encoding the GnRH II receptor in humans, and its cloning and sequencing from monkey and pig tissues. They also reported that GnRH II mRNA's expression, as measured using an antisense riboprobe, is totally ubiquitous (21 different tissues of human origin with highly variable degrees of expression) (Neill et al. 2001). This large distribution of the GnRH II receptor in human tissues parallels that observed earlier for GnRH I receptor. Such findings suggest the existence in humans of a widespread paracrine or autocrine regulatory system (Neill et al. 2004).

Expression of the GnRH II receptor has been demonstrated in cell lines derived from human endometrial and ovarian cancers. Proliferation of these cell lines was reduced by GnRH II in a time- and dose-dependent manner, at equimolar doses much lower than a GnRH I superagonist. Since all endometrial and ovarian cancer cell lines express GnRH II receptors and GnRH II has more potent antiproliferative properties on tumor cell growth than GnRH I, even more powerful analogs of GnRH II or non-peptidic mimics may be worth exploring as antitumor agents (Grundker et al. 2002, Tang et al. 2002).

$\mathrm{GnRH}$ receptors have been reported in biopsies of glioblastoma, melanomas (van Groeninghen et al. 1998), and in two melanoma cell lines with evidence that GnRH superagonists inhibited proliferation and invasiveness (metastatic potential) in an in vitro model (Moretti et al. 2002). Labeled analogs of GnRH have also been used to scan possible dissemination (metastases) of various tumors when a biopsy showed binding of GnRH I or II.

\section{GnRH analogs as superagonists or antagonists}

As is the case for all these native hypothalamic peptides, half-lives are very short ( $\mathrm{min}$ ) as they are rapidly degraded by various enzymes in blood or tissue fluids. Very early after the sequencing of porcine and ovine $\mathrm{GnRH}$ a series of agonist analogs were reported with increased potency either due to metabolic stability or greater receptor affinity. To date, a very large number of these analogs have been produced in academia and in industry. It was also early recognized that these agonist analogs with greater specific activity than the native decapeptide, the superagonists, produced an immediate increase in LH and FSH secretion, which was consistently followed by a state of inhibition of secretion of the gonadotropins and gonadal steroids, a typical example of the ligand-induced downregulation of the receptors. Such GnRH superagonists have been successfully used in the treatment of endometriosis, primary precocious puberty, prostate cancer and 
as a pre-operative treatment of large leiomyomas. When used in long-term therapies it has been customary to include so-called 'add back' regimens during which synthetic sex steroids are administered in well controlled doses along with the superagonist to overcome the side effects such as hot flashes, bone resorption and osteopenia.

A series of true $\mathrm{GnRH}$ antagonists are also available which bind to the receptor without activating it and prevent binding of the normal ligand $\mathrm{GnRH}$. The obvious advantage of these analog antagonists is that they produce an immediate decrease in circulating gonadotropins and gonadal steroid levels, easily reversible and never preceded by the surge seen with the superagonists. Unexpectedly, some of the early $\mathrm{GnRH}$ antagonists were shown to stimulate release of histamine by mast cells, an undesirable side effect. Newer compounds have practically overcome the problem. These GnRH antagonists are currently used in medicine for the same indications mentioned above for the superagonists, with the additional advantage that the initial flare-up in gonadotropin secretion is avoided. One of these antagonists is currently approved for use in preventing premature LH surge in ovulation induction in in-vitro fertilization programs. In patients with cancer of the prostate long-term use of the antagonists leads to well controlled lowering of plasma androgens levels (Yen 2004, Yen \& Jaffe 2004). More recently, some nonpeptidic antagonists have been synthesized with the idea that they could be active orally. Two such compounds are in early clinical trials with satisfactory results. In long-term therapy judicious dosing of the antagonist would eliminate 'add back' regimens.

In closing this section on GnRH, I will review briefly the current knowledge about the ontogeny of the neurons which eventually control the sex life of all vertebrates. During early development, at about the same time as gonadotropins appear in the progenitor cells of the pituitary, neurons expressing GnRH are found in the epithelium of the olfactory placode (Wray et al. 1989) and in the nervus terminalis (also referred to as cranial nerve zero or terminal nerve), a differentially organized set of nerve fibers comingled with chains of GnRH-containing neuronal cell bodies extending peripherally to the lamina propria of the nasal chemosensory mucosa and centrally to the ventral forebrain where they eventually establish an adult-like distribution. Progenitors of neurons expressing GnRH-mRNA and peptide product (only GnRH1) and GnRH receptors, and destined for the preoptic area, migrate from the olfactory placode, crossing into the septal-preoptic area apparently following gradients of the adhesion molecule neural cell adhesion molecule (NCAM) and the axonal growth promoting protein, netrin (Schwarting et al. 2004). Gamma-aminobutyric acid (GABA), which is also found in a population of these GnRH neurons, has also been implicated in this migratory development (Tobet et al. 1996). Recent studies have shown that some of the early GnRH neurons remain in the nasal cavity, including the olfactory and vomeronasal mucosa, in the adult including humans (Wirsig-Wiechmann 2001). These peripheral GnRH processes terminate within the lamina propria of the chemosensory mucosa. GnRH receptors are also expressed by chemosensory neurons. Thus, paracrine release of GnRH may well influence the function of the chemosensory neurons as patch clamp recording techniques have shown, in rodents, that GnRH increases sodium conductance in olfactory neurons (Wirsig-Wiechmann 2001). GnRH may thus be involved or responsible for the traditional reports of increased sexual activity (arousal) induced by body odors at some times of the menstrual cycle in women, and in the overall functions of pheromones in general. The elucidation of this unique origin of the GnRH neurons before they reach their ultimate hypothalamic location and function explains both the anosmia either complete or selective and the isolated gonadotropin deficiency in patients with one form or another of Kallmann's syndrome and related developmental abnormalities (Lieblich et al. 1982). See also a recent report (Rugarli et al. 2002) implicating a unique protein (KAL), the gene product of $K A L-I$, in the terminal steps of olfactory axon guidance, connections with the early GnRH neurons and possibly other peripheral axonal mappings.

\section{Somatostatin}

When we first isolated, sequenced and synthesized somatostatin from hypothalamic tissues in 1972 (Brazeau et al. 1973) it was a physiologically unexpected inhibitor of the pituitary secretion of growth hormone. Indeed, we were searching for a growth hormone releasing factor. Rapidly, it was shown by Charlie Gale in Seattle to produce hypoglycemia in their baboons, related to inhibition of the secretion of glucagon and insulin, a fact confirmed by Sam Yen in acromegalic patients; Dubois in France and Rolf Luft and Thomas Høkfelt in Stockholm showed that somatostatin was synthesized in the delta cells of the endocrine pancreas. Rapidly again, the group around Michael Besser in London was to show effects of somatostatin on the secretion of gastrointestinal peptides as well as immunolocalization of somatostatin in the pertinent secretory elements (Albinus et al. 1975).

And in a Starling Review, it is only fitting to mention that secretin was shown to be a powerful stimulator of the secretion of pancreatic somatostatin in a perfused $\operatorname{dog}$ pancreas preparation (Ipp et al. 1977).

The early observations on multiple activities of the peptide, unrelated to growth hormone secretion, were followed by the synthesis both in academia and the pharmaceutical industry of a very large number of analogs of the native structure of somatostatin with the aim of dissociating the multiple activities of the peptide and 
improving on the short half-life of the native molecule. Availability of these analogs led to the characterization of somatostatin receptors in multiple tissues. We know now that there exist 5 different receptors, with isoforms, and their tissue distribution is now well known (Raulf et al. 1994). They have been cloned and expressed and knockout animals have been prepared.

Thus, there is now extensive evidence that somatostatin also originates from the immune system and has significant immunomodulatory activity. The thymic epithelial and dendritic cells synthesize somatostatin and express type 2 somatostatin receptors. Somatostatin is now recognized to be part of an immunoregulatory circuit that inhibits production of interferon-gamma, tumor necrosis factor $\alpha$ (TNF $\alpha$ ), CRH and Substance P at sites of (chronic) inflammation (Karalis et al. 1994, Weinstock \& Elliott 2000). Locally released somatostatin has been reported to be involved in the classic anti-inflammatory action attributed to glucocorticoids (Karalis et al. 1995). A recently discovered variant of somatostatin, named cortistatin because of its prevalence in the brain cortex, has also been shown to be expressed in human monocytes, monocyte-derived macrophages and dendritic cells both in the normal state and when activated by various lipopolysaccharides. Both cortistatin and somatostatin bind to type 2 somatostatin receptors (Elliott et al. 1999, Weinstock \& Elliott 2000), more specifically the isoform 2A. T cells and $\mathrm{B}$ cells, like macrophages, express mRNA for the receptor type 2. Thus, somatostatin can be considered as an immunoregulatory cytokine that regulates inflammation. Intra-articular injection of somatostatin or one of the analogs has been reported to reduce synovitis and inflammation in patients with rheumatoid arthritis (Coari et al. 1995). It also reduces the concomitant pain possibly because, in a new twist and as recently demonstrated, somatostatin also binds to the mu-opioid receptor. $\mathrm{Mu}-$ opioid receptors in the skin, particularly in the keratinocytes, are involved in the perception of peripheral pain. Analogs of somatostatin such as octreotide and lanreotide have much greater affinity to the mu-opioid receptor than the native peptide.

A few words about cortistatin, the neuropeptide with high homology with somatostatin expressed in most tissues along with somatostatin, but primarily in brain cortex, hence its name. Cortistatin-14 inhibits GH release in response to GHRH at the same doses as somatostatin-14. Cortistatin binds to all somatostatin receptors, but unlike somatostatin, also binds to the ghrelin receptor (see the section on GHRH below). Both peptides at equivalent doses similarly inhibit GH release induced by ghrelin (Broglio et al. 2002).

Somatostatin analogs have been reported to inhibit angiogenesis in vitro and in vivo through receptors present on endothelial cells and also through inhibition of paracrine growth factor secretion such as IGF-I, vascular endothelial growth factor (VEGF), and FGF-2. Two excellent reviews have recently appeared (Reubi 2003, Weckbecker et al. 2003) describing the native sequences of somatostatin in various species, somatostatin analogs, mechanisms of action, the receptors (Weckbecker et al. 2003), the use of labeled analogs and their use in diagnostic and therapeutic opportunities (Reubi 2003).

Scintigraphy with labeled analogs of somatostatin has shown the presence of several types of receptors in pathological peripheral tissues, including the retro-orbital tissue in Grave's disease. Accumulation of the radionuclide is correlated with the presence in the orbital tissue of activated lymphocytes, and treatment with octreotide has been reported to improve the ophthalmopathy (Krassas \& Kahaly 1999). The same technique of scintigraphy with a labeled analog such as octreoscan has led to the recognition that many cancers express specific somatostatin receptors. Somatostatin receptors scintigraphy in primary breast cancer has been reported to correlate with expression of the subtype $2 \mathrm{~A}$ and type 5 receptors, including in metastases (Schulz et al. 2002). Malignant melanomas including uveal melanomas have been shown to express somatostatin receptors (SST-R), particularly SST-R2 and $-\mathrm{R} 5$. Somatostatin analogs have been proposed in the treatment of these tumors, either alone particularly as high-energy radioisotope-labeled peptide (octreotide) or as adjuvant therapy. Similar observations and conclusions have been made and proposed in cases of small cell lung cancer and bronchial carcinoid disease (O'Byrne et al. 2001). In fact, all so-called neural crest or neuroendocrine tumors (insulinomas, glucagonomas, gastrinomas) have been shown to express somatostatin receptors and to respond, sometimes dramatically, to long-acting analogs of somatostatin. A large number of reports deal with adenocarcinoma of the prostate. It has been known for years that all prostatic tumors contain cellular elements known as neuroendocrine cells as they are positive in immunocytochemistry for a variety of peptides such as bombesin, TRH, somatostatin, chromogranin A and also serotonin (Hansson \& Abrahamsson 2001). The degree of differentiation and proliferation of these cells appears to correlate inversely with tumor progression and the appearance of the androgen independent state. It has been proposed (Zapata et al. 2002) that cancerous epithelial cells become responsive to paracrine and autocrine factors from the neuroendocrine cells by up-regulation of receptors for these neuropeptides. In cell lines such as PC3, analogs of somatostatin binding to type 2 and type 5 receptors inhibit proliferation. Thus the correct analog of somatostatin in relation to the particular receptor expressed may become part of the therapy of some of these tumors (Weinstock \& Elliott 2000, Mosca et al. 2004).

\section{CRF, CRH}

In keeping with the historical nomenclature vagaries I mentioned above, the originally named CRF is still CRF 
in much of the literature rather than $\mathrm{CRH}$, but both terms are used. When in the 1950s Hans Selye was calling attention to the importance of 'the first mediator' of the ACTH response upon exposure to stress, which was finally characterized as a 41 residue peptide 30 years later by the group led by W Vale (Vale et al. 1981), he had no suspicion of the extraordinary multiplicity of actions of that molecule which is involved in the normal response(s) to stress besides the activation of the secretion of ACTH. Two major reviews have been published on CRF, its variants, multiple receptors, mechanism of action, multiple physiological functions and clinical implications (De Souza \& Nemeroff 1990, Bale \& Vale 2004).

As could be expected for a molecule of that physiological importance, the primary sequences of the several CRF variants and related molecules (urocortins I, II, III) share major identities from amphibians to several mammalians including humans.

The action of CRF and CRF-related molecules are mediated through G-protein coupled receptors derived from two distinct genes, CRF-type 1 (CRF-R1) and CRFtype 2 (CRF-R2) receptors. Both receptors have different anatomical distributions and physio-pharmacological properties and exist in several isoforms (Ehrhart-Bornstein et al. 1998).

In situ hybridization for CRF-mRNA has shown both message and peptide (CRF-41) in a subpopulation (the parvocellular neurons) of the paraventricular nucleus, surrounding the vasopressin synthesizing neurons (Grino et al. 1989, De Souza \& Nemeroff 1990), the central nucleus of the amygdala, the midbrain (substantia nigra and periaqueductal gray) and the dorsal vagal complex of the medulla. In these locations, CRF is primarily involved in ACTH-stress response and, as could be expected, its levels are modified by adrenalectomy and glucocorticoid administration as well as by acute or chronic stress exposure. CRF-41 has been found in hypophysial portal vessels together with vasopressin but not urocortin. Similarly, mice deficient in urocortin I (knock-out) have normal levels of plasma ACTH and show a normal response to stress entirely mediated by CRF (Bale \& Vale 2004).

A CRF-binding protein (37 kilodaltons) (CRF-BP) has been characterized and is expressed in the brain, the pituitary and peripheral tissues (liver, kidney, spleen). The ligand site for the binding protein is different from that of the main receptor, CRF-R1 for CRF. CRF-BP may play a role in limiting the distribution or duration of action of CRF.

Urocortin I is expressed in neurons of the EdingerWestphal nucleus of the midbrain, the gastrointestinal tract, testes, cardiac myocytes, thymus, skin, and spleen, while urocortin II and III are also found in the hypothalamus.

Recent and still ongoing studies on the CRF receptors and ligand have shown that CRF has a tenfold higher affinity for CRF-R1 than for CRF-R2, while urocortin I binds with equal high affinity to both receptors, in all locations; in contrast urocortin II and III are selective for CRF-R2. Both receptors are found throughout the CNS, CRF-R1 being prevalent; it is found throughout the cerebral cortex, cerebellum, olfactory bulb, medial septum, hippocampus, amygdala and the pituitary. CRF-R2 is found primarily in hypothalamus, lateral septum, and also in the choroid plexus. CRF and CRF-mRNA are found in the cerebellum of several species (Cummings et al. 1994), particularly in the two primary afferent systems, i.e. the climbing fibers and the mossy fibers (Palkovits et al. 1987) and the two CRF receptors (CRF-R1 and CRF-R2) have been demonstrated in similar locations (Bishop et al. 2000). CRF potentiates both spontaneous and glutamate-induced activity of Purkinje cells (Bishop \& King 1992). CRF has been found to be essential for induction of long-term depression in the cerebellum, a mechanism which has been proposed for consolidating motor learning (Ito 2001). There is now evidence that the amounts of CRF that can be measured in various regions of the cerebellum vary in direct relation to the degree of electrical stimulation that can be applied to those regions of the cerebellum, thus implying that CRF is a necessary neuromodulator component of cerebellar function. CRF and its mRNA have been localized not only in varicosities of the climbing fibers but also in primary axons (Tian \& Bishop 2003).

That report also showed the presence of CRF in radial glial cells and astrocytes both in the granule cell layer and within white matter and stated that the amount of the peptide was significantly changed following stimulations of two afferent regions of the cerebellum. Increased c-fos expression was also observed in the same loci following stimulation. While the authors were particularly cautious in constantly referring to CRF-like immunoreactivity (CRF-LIR) in all these studies in case other peptides known or unknown might be recognized by the antibody, these results are remarkable as they show CRF to be directly involved in the actual functioning of cerebellar neuronal systems. Parallel results have been reported for CRF neurons in hippocampal and cortical regions of the immature rat brain (Brunson et al. 2002) following stress exposure.

In an extensive series of experiments with brain slices maintained in vitro, Liu et al. (2004) have recently demonstrated an even more refined implication of CRF and urocortin I in modulating excitatory glutamatergic transmission in two limbic nuclei (the central nucleus of the amygdala and the lateral septum mediolateral nucleus), with evidence of the functional demonstration of the two receptors CRF-R1 and CRF-R2 on neurons of these two nuclei which are known also to express the peptides or to be innervated by fibers containing the peptides. Activation of one or the other receptor by the peptide ligand leads to opposite effects on overall glutamatergic transmission in 
these nuclei. The proposed effects observed provide more evidence of the functional modulatory role of the peptides in 'classic' synaptic transmission (here glutamatergic). Here may be the mechanism whereby CRF, urocortin I and related ligands contribute to normal or abnormal processes involved in normal behavior, or in anxiety, fear or depression as has been shown in a number of studies (see below).

Reminiscent of what we saw earlier with leptin and TRH, CRF has been reported to trigger neurite outgrowth in a catecholaminergic cell line (Cibelli et al. 2001).

At the periphery, CRF-R2 is widely expressed in the gastrointestinal tract, the lung, skeletal muscle, arteries and heart muscle. Indeed, peripherally injected CRF increases gastrointestinal motility, inhibits gastric secretion, lowers blood pressure and affects heart output, and decreases inflammatory reactions. The two receptors are probably involved in some coordinate ways to express the totality of the physiological responses to stress including behavioral responses/components (more below).

CRF family members are now recognized to be involved in regulating cardiovascular hemodynamics, vascularization and cardioprotection. Early studies had reported that CRF decreases mean arterial pressure and increases superior mesenteric artery flow. With the demonstration of CRF-R2 and its mRNA in cardiac myocytes and arterial walls it was confirmed that urocortin I is the active ligand for the inotropic action on the heart and vasodilation. CRF-R2 activation decreases release of VEGF from arterial smooth muscle cells, inhibiting their proliferation in in vitro studies, and in the same studies urocortin I was shown to inhibit the proliferative effects of VEGF with obvious implications of a possible role of the peptide in controlling angiogenesis in tumor growth and other syndromes. Urocortin I has also been shown to protect cardiac myocytes from lethal ischemic injury while at the same time it stimulates ACTH secretion since it is a ligand for CRF-R1 and CRF-R2. Urocortin II and III, which are specific ligands for CRF-R2 beta, the receptor expressed in the heart, do protect cardiomyocytes from ischemic reperfusion injury in studies in the rat, with only minor activation of the hypothalamic stress axis. Urocortins II or III may turn out to be important agents in treating ischemic heart disease (Bale \& Vale 2004, Brar et al. 2004).

Unexpectedly, CRF and CRF-binding sites have been demonstrated in the adrenal medulla, mostly in layers of cells adjacent to the cortex, and administration of CRF in vitro or in vivo in hypophysectomized animals stimulates secretion of glucocorticoids as does stimulation of the splanchnic nerve (Ehrhart-Bornstein et al. 1998). Here, we see one of the increasing cases where a ubiquitous CRF may be and may act as, a paracrine secretory product. CRF, urocortin and stresscopin (urocortin III) along with the CRF-R1 and CRF-R2 receptors have recently been demonstrated in (human) adipose tissue. CRF-R2 shows a higher level of expression in visceral fat than in subcutaneous fat, the opposite being the case for CRF-R1. CRF regulates adipocyte metabolism (cortisol production) by down-regulating 11-beta-hydroxysteroid dehydrogenase and thus may be involved in the overall mechanism of energy homeostasis (Seres et al. 2004).

CRF and the urocortins along with their specific binding sites thus appear to be ubiquitous and there is now overwhelming evidence that they are involved in acute and chronic responses to endogenous or exogenous assaults to homeostasis of the whole organism. The results mentioned above both in the cerebellum and the limbic system also imply that CRF is involved in functions of the neural network, well remote from its hypophysiotropic role.

There is extensive and well supported evidence that this includes mental pathology. A large body of evidence implicates CRF in the development of major depression and several types of anxiety behavior as well as in the behavioral consequences of early life stress (Owens \& Nemeroff 1999, Brunson et al. 2001). Several studies in CRF-R1 knockout mice have consistently shown anxiolytic effects. However, since the CRF-R1-null-animals show a marked reduction in circulating glucocorticoid hormone levels, it was difficult to differentiate a specific role of CRF-R1 on behavior from that due to the low glucocorticoids, as it is well known that the steroids are importantly involved in modulating fear and anxietyrelated behavior. A recent study (Muller et al. 2003) has reported that in mice in which CRF-R1 functions are inactivated postnatally in the anterior forebrain and limbic structures but not in the pituitary by 'conditional knockout', the animals showed reduced anxiety, while the basal activity of the hypothalamic-pituitary-adrenal axis remained normal, thus implicating brain CRF-R1 and its ligands in anxiety behavioral response to stress (Fig. 3).

Antagonists of CRF at the receptor (CRF-R1) level (peptides related to the amino acid sequence of CRF or non-peptidic small molecule derivatives of pyrrolpyrimidine) have been extensively studied in a large number of animal paradigms for anxiety-related behavior, with significant results. Early clinical trials have been reported on several small molecules. Liver toxicity led to early termination of a Phase II study for one of these otherwise promising compounds. All the compounds so far investigated are highly lipophilic, which may be related to the liver-enzyme effect. Extensive studies are ongoing to validate CRF-R1 antagonists as clinical agents in anxietyrelated illness (Zorrilla \& Koob 2004).

Thus it can be proposed that the CRF family of molecules and their receptors are involved in controlling many of the components of allostasis triggered by stress including behavioral comportments, and the recent results showing CRF, urocortins and CRF-R2 expression in adipocytes as well as the role of urocortins on food intake now implicate the CRF peptides in the regulatory mechanisms leading to energy homeostasis of the whole organism. 


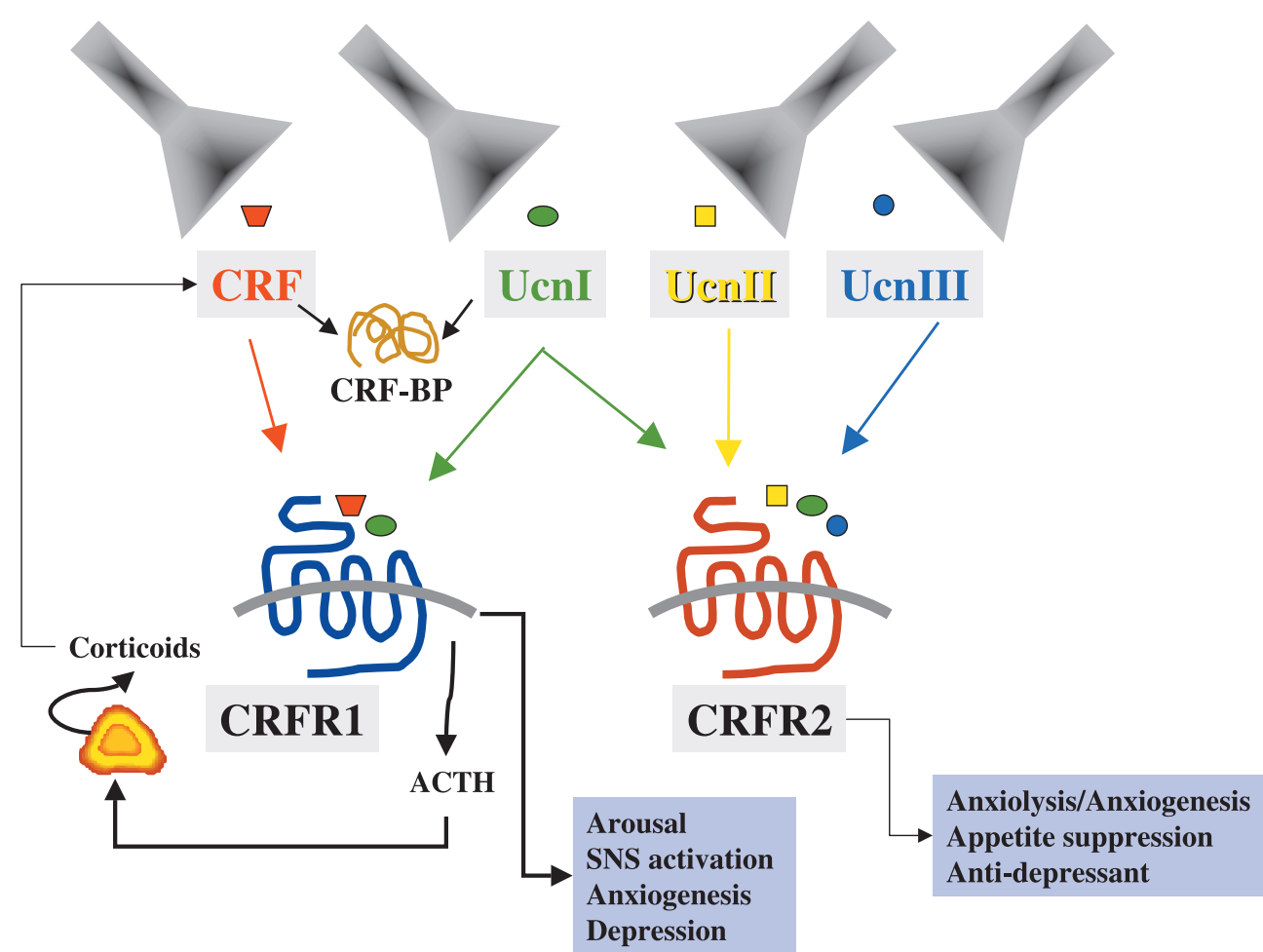

Figure 3 Summary of CRF ligand and receptor specificity and physiological and behavioral effects of receptor activation. Ucn, urocortin. From Bale and Vale 2004.

\section{GRF, GHRH}

As seems to be the rule and as concluded in the writing of this review, the simple statement that could be made by Wehrenberg et al. in 1982 that the secretion of growth hormone is controlled by the combined actions of the hypothalamic growth hormone releasing factor (GRF, GHRH) and somatostatin' is not so simple anymore. That conclusion is due mainly to totally unexpected results which came from the inventive mind of C Y Bowers searching for small molecules à la enkephalins which, like opiates, would stimulate the secretion of growth hormone. Indeed, after a few years of successive hesitation and clarity a series of small (4-6 residues) peptides were described with powerful GH-releasing activity both in vitro and in vivo and with evidence that they were acting by mechanisms and through receptors different from those associated with the 44-residue GRF recently isolated from the hypothalamus (through the circuitous route of having been first characterized in a (human) tumor of the pancreas that had caused acromegaly). Nonpeptidic small molecules referred to as $\mathrm{GH}$ secretagogs with widely different molecular structures (Patchett et al. 1995) were also shown to stimulate release of growth hormone. Careful about their appraisal of the physiological results being obtained with the hypothalamic GRF, by that time available in unlimited quantities from total synthesis, Bowers and his collaborators proposed that their small, unnatural peptides (up to $3 \mathrm{D}$-amino acids in a pentapeptide) which they named 'growth-hormone releasing peptides' (GHRP) must be acting through an orphan receptor (Bowers 1999), the additional hypothesis being that these $\mathrm{GH}$ secretagogs may mimic some unknown endogenous substance different from hypothalamic GHRH. By that time, a cDNA encoding the GHRH receptor in pituitary tissue had been cloned, corresponding to a G-protein coupled receptor involving adenyl cyclase, cAMP and protein kinase A. A few years later, a group at Merck Research Laboratories cloned the growth hormone secretagog receptor and showed it to be a G-protein coupled signaling pathway via phospholipase $\mathrm{C}$, inositol triphosphate and protein kinase $\mathrm{C}$, i.e. quite different from the GHRH-receptor (Bowers et al. 2004). Unexpectedly the GH secretagog receptor was observed both in the pituitary and the hypothalamus in a subpopulation of the arcuate nucleus known to contain the GHRH-secreting neurons.

Finally, a novel endogenous ligand, first found in extracts of rat stomach mucosa, was characterized for that receptor. It was shown to be a novel 28 amino acid linear peptide in which the serine-3 residue (Kojima et al. 1999) is acylated by an n-octanoyl side chain. Named ghrelin, the human form was shown to be homologous to rat-ghrelin with only two residues different. The octanoyl at serine-3 is necessary for biological activity (Bowers 2001). 
However, new results show unacetylated ghrelin to have significant biological activities of its own or in combination with ghrelin (Bedendi et al. 2003, Broglio et al. 2004, Gauna et al. 2004). As expected from the earlier results on the receptors, the novel ligand ghrelin is also found in a separate population of arcuate neurons.

The ultimate physiological control of the secretion of growth hormone is by now multilevel and not totally clear. Hypothalamic GHRH stimulates secretion and that action is antagonized by somatostatin; hypothalamic and/or gastric ghrelin potentiates the effect of GHRH or adds its action to that of GHRH; ghrelin appears to antagonize or decrease the secretion of hypothalamic somatostatin (Fig. 4).

In normal subjects ghrelin has been reported to stimulate release of $\mathrm{GH}$ in much greater amounts than maximal doses of GHRH, indicating a different mechanism of action at the pituitary level (Takaya et al. 2000); the concomitant administration of GHRH and ghrelin by i.v. bolus produces the highest level of plasma GH ever recorded, with the proposal that continuous ghrelin infusion would induce sustained increases in pulsatile $\mathrm{GH}$ secretion and IGF levels (Bowers 2001). Because some laboratory studies in the rat have yielded conflicting results when compared with the human data (definite desensitization of pituitary GH secretion to repeated doses of GHRP or ghrelin) an ultimate and satisfactory explanation of the inter-relationships between GHRH, somatostatin and ghrelin is still to be explored.

Hypothalamic GHRH is highly specific for the secretion of growth hormone, while ghrelin in laboratory animals and humans stimulates also the secretion of ACTH and prolactin, but not TSH, LH, or FSH. Interestingly enough, in laboratory animals or in man, it looks as if GHRP and/or ghrelin work by potentiating endogenous GHRH: the combined administration of GHRP or ghrelin with a GHRH-antagonist inhibits the GH response to that dose of GHRP or ghrelin (Pandya et al. 1998, Bowers 2001).

Any effort to understand the role of ghrelin in the physiological control of $\mathrm{GH}$ secretion must take into consideration its secretory pattern in relation to food intake, together with its possible role on appetite control (along with other hypothalamic factors such as NPY, galanin, and orexin as stimulators, CART, cholecystokinin (CCK), aMSH, glucagon-like peptide-1 (GLP-1), peptide $\mathrm{YY}$, and urocortin as inhibitors). The respective roles of gastric versus hypothalamic ghrelin on GH release remain to be clarified.

GHRH, ghrelin and their respective messages have been located in the anterior pituitary, leading to the proposal of some autocrine role of the peptides. This concept is further expanded by the demonstration of a ghrelin receptor in the pituitary. GHRH infusion increases pituitary levels of ghrelin-mRNA and of ghrelin. Consistent with this observation, pituitary ghrelin expression is decreased in situations where hypothalamic GHRH
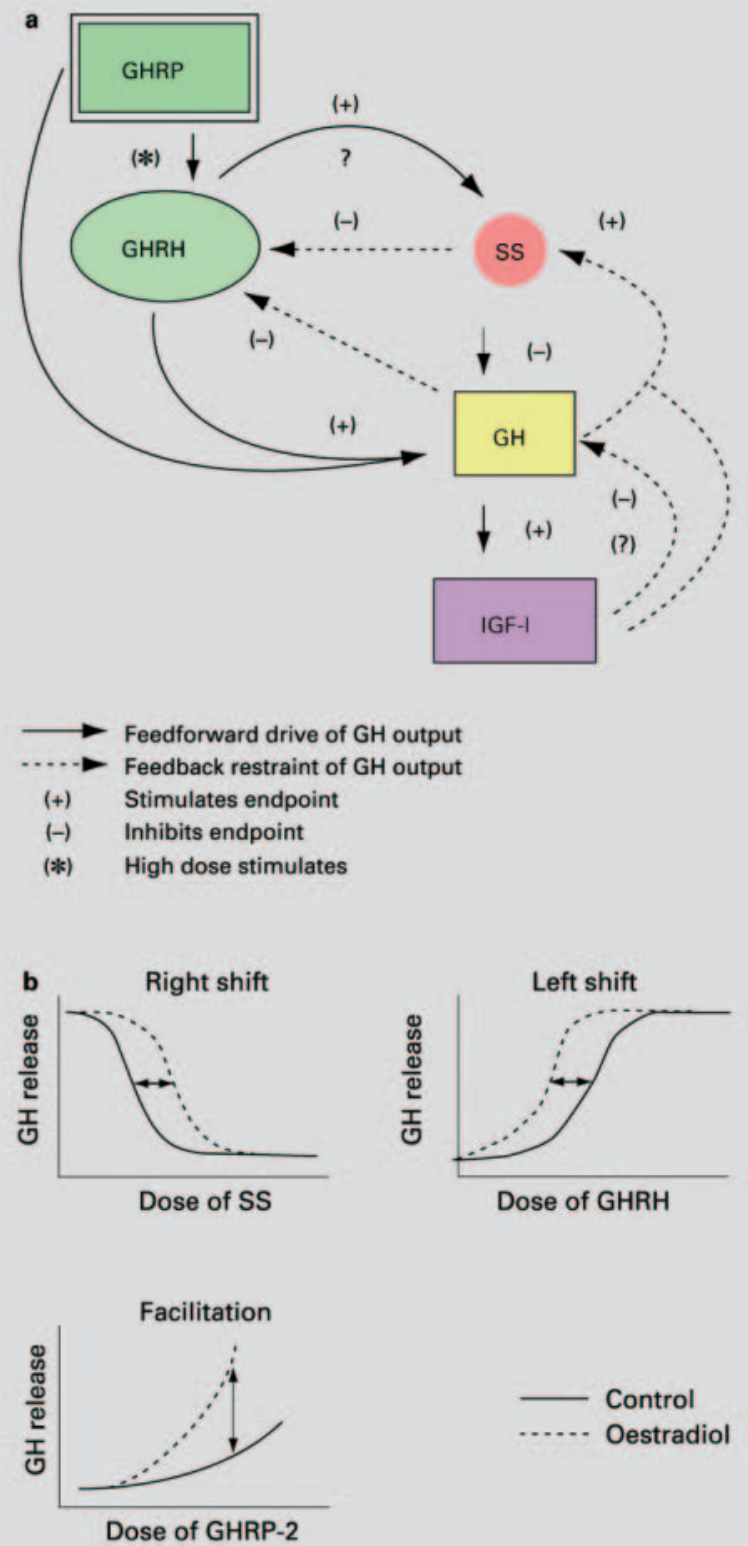

Figure 4 (a) Concept of ensemble control of $\mathrm{GH}$ secretion by GHRH, GHRP/ghrelin, somatostatin (SS), GH and IGF-I. (b) Sites and mechanisms of action of estradiol on feedback by SS (top left) and feedforward by GHRH and GHRP-2 (top right and bottom left) discerned by infusion of a single effector dose of estradiol in post-menopausal women.

From Veldhuis (2003).

expression is decreased such as $\mathrm{GH}$ administration, glucocorticoids excess, hyperthyroidism and food deprivation. These results suggest that GHRH controls pituitary ghrelin expression. In the presence of a specific inhibitor of the ghrelin receptor, the GH response to GHRH was 
significantly reduced, showing that ghrelin can modulate the responsiveness to GHRH (Bowers 2001).

In parallel with what we saw earlier regarding the effects of somatostatin and its analogs on and in the immune system and on the control of tumoral growth, a series of interesting papers have called attention to the novel involvement of GHRH. A series of synthetic peptide analogs of the sequence 1-29 of GHRH with multiple substitutions have been shown to be powerful antagonists of GHRH on growth hormone release, in vitro and in vivo (Kovacs et al. 1996, Varga et al. 2004) in laboratory animals with significant effects on the production of IGF-I as measured by plasma levels in some reports. With this observation Schally and collaborators have reported that the most potent of these GHRH antagonists decrease or inhibit the rate of growth of several tumors in vitro or when implanted in nude mice (HT-29 human colon cancer, SW-1990 human pancreatic cancer, NCI-H838 non-small cell lung carcinoma).

They have reported that some of these GHRH antagonists, while not necessarily modifying IGF-I plasma levels, do decrease significantly IGF-I and IGF-II and their mRNA levels in implanted tumoral tissue as well as in vitro (Szepeshazi et al. 2000a,b). These results led the authors to consider a direct effect of GHRH on the proliferation of cancer cells, acting as a growth factor.

Recently, the same group has reported that these GHRH antagonists enhance the antitumor activity of inhibitors of androgen production (flutamide, LH-RH superagonists) in an experimental model of human androgen-sensitive MDA-Pca-26 prostate carcinoma implanted in nude mice (Letsch et al. 2004). Any proposal for a clinical application for these GHRH-peptide antagonists which would involve chronic administration of the molecule, will, no doubt, have to take into consideration that they will very likely trigger antigenicity, in view of the unnatural substitutions introduced in the amino acids sequence.

In closing, we can conclude that the primary activator of the secretion of $\mathrm{GH}$ by the pituitary would still be hypothalamic GHRH, ghrelin being some sort of modulator of the basal GHRH action, that could explain the nocturnal surges of $\mathrm{GH}$ secretion and possibly the reduced frequency of pulsatile secretion of GH. It is also possible that GHRH expressed in tissues other than the hypothalamus may have significant autocrine or paracrine activities. This short review can only conclude here that the ultimate roles of GHRH and ghrelin in relation to $\mathrm{GH}$ secretion remain to be fully elucidated and also, in tribute to C Y Bowers, that his bold starting hypothesis led him to a major discovery.

\section{Conclusions: a look to the future}

How can one conclude such a review other than by saying that its subject is far from being concluded? In reading these many reports I have been more and more surprised at the ubiquity of these five original 'hypothalamic hypophysiotropic peptides', the multiplicity of their physiological functions in relation to their localization in the central nervous system, other than in the hypothalamus, and at the periphery in all tissues and organs where they have been searched for, and found, along with the now well recognized multiple receptors. In these locations, most if not all of their biological activities are best explained by paracrine and even autocrine mechanisms, some of which have been clearly demonstrated. So, if these substances, in producing their biological activity, do not have 'to be carried from the organ where they are produced to the organ which they affect by means of the blood stream' in the very words of Starling himself (Starling 1905b), may we call them hormones or releasing factors (quid somatostatin)?

Some years ago (Guillemin 1978), I proposed the name cybernin for (these) substances, the etymology of the word implying local control $(\kappa \nu \beta \varepsilon \rho \nu \eta \tau \eta \varsigma$, the rudder of a boat or the pilot of a ship). We might consider using the word in some generic way (e.g. GnRH acting as a cybernin in prostatic tissue). But let us not get over-occupied and certainly not over-protective with nomenclature. Science, biology in particular, is full of remarkable progress involving many substances the original name of which implies a function which turns out to be the least important in the overall significance of the molecule in question (vasopressin, somatostatin, lipotropin $(\beta \mathrm{LPH}) \ldots$. .). In the vagaries of nomenclature with which I started this review, perhaps the best names are those that mean nothing (substance P, peptide Y, quarks... with a bow to Murray Gell-Mann ...).

In the lecture I mentioned above I had called attention to the fact that none of these molecules - the hypothalamic releasing factors, which we were beginning to find all over the brain - were even mentioned in the then current texts of psychiatry and that it was a safe and heuristic proposal that they would sooner or later be found to be involved in normal and abnormal behavior in psychiatry. The recent reports mentioned above with $\mathrm{CRH}$, somatostatin, and TRH in multiple brain functions and post trauma anxiety reactions are in keeping with such a future in clinical medicine. This is particularly true for CRF and the urocortins in their native molecular structures or, more likely, in some structural analog or in the guise of some nonpeptidic ligand to one or the other of the receptors, as can now be designed with exquisite precision. The recent and still ongoing observations on the effects and roles of CRF-urocortin in cardiac functions is another promising area. I personally think that some analog of somatostatin will become a major treatment of chronic inflammations. Already functional and certainly to be developed is the use of radio-labeled analogs of these peptides in well controlled conditions of correct ligand-receptor correspondence as ascertained in relatively simple in vitro testing from biopsy specimens, for imaging disseminated tumors and possibly 
destruction. I think that it will be of interest to investigate the possibility of using either sequentially or simultaneously several antagonists of GnRH, GHRH in the treatment of tumors after biopsies have demonstrated which peptide(s)-receptor(s) may be involved in tumor growth. There is, indeed, increasing evidence of multiple peptide receptors in many tumors, particularly those derived from tissues of ectodermic origin. A somatostatin analog for the one receptor involved could be part of that medication cocktail. With a wider view still, the current advances in availability and screening of the sequence data for human and other genomes are ways to identify new members of protein families, ligands and receptors which may well shed totally unexpected new lights on the functions of these molecules. I am also intrigued by the possibility, of which we saw several examples, of these peptides being involved in the structural buildup, almost like 'growth factors', of de novo neurites, dendrites and their persistence, in what may be the physical support, substrate, of what will, one day, be understood as memory.

Jonas Salk used to say: 'We must be good ancestors'. I think that those of us originally involved with the five hypothalamic hypophysiotropic peptides may fit this description, in the distinguished company of Ernest Henry Starling.

\section{Acknowledgements}

I would like to express my gratitude to friends-colleagues who kindly provided me with recent or unpublished papers (W Vale, G Koob, CRF; C Y Bowers, GHRP; K Bauer, TRH; Sam Yen, GnRH; J Neill, GnRH-R2) and made my life easier in the writing of this review. My thanks also to Professor Anthony Edward, UCSD, Dept. of Literature, for his help with the quotation from the Iliad, and to my Administrative Assistant, Bernice Walker, who has been involved in these writings for almost as long as I have.

\section{References}

Albinus M, Blair EL, Grund ER, Reed JD, Sanders DJ, Gomez-Pan A, Schally AV \& Besser GM 1975 The mechanism whereby growth hormone-release inhibiting hormone (somatostatin) inhibits food stimulated gastric acid secretion in the cat. Agents Actions $\mathbf{5}$ 306-310.

Bale TL \& Vale WW 2004 CRF and CRF receptors: role in stress responsivity and other behaviors. Annual Review of Pharmacology and Toxicology 44 525-557.

Bauer K 2004 TRH-degrading aminopeptidase: a regulator and terminator of TRH action? In Aminopeptidases in Biology and Disease, pp 127-143. Eds U Leudeckel \& N Hooper. New York, NY: Kluwer Plenum Publishers.

Bedendi I, Alloatti G, Marcantoni A, Malan D, Catapano F, Ghe C, Deghenghi R, Ghigo E \& Muccioli G 2003 Cardiac effects of ghrelin and its endogenous derivatives des-octanoyl ghrelin and des-Gln14-ghrelin. European Journal of Pharmacology 476 87-95.
Bishop GA \& King JS 1992 Differential modulation of Purkinje cell activity by enkephalin and corticotropin releasing factor. Neuropeptides 22 167-174.

Bishop GA, Seelandt CM \& King JS 2000 Cellular localization of corticotropin releasing factor receptors in the adult mouse cerebellum. Neuroscience 101 1083-1092.

Bohlen P, Brazeau P, Bloch B, Ling N, Gaillard R \& Guillemin R 1983 Human hypothalamic growth hormone releasing factor (GRF): evidence for two forms identical to tumor derived GRF-44-NH2 and GRF-40. Biochemical and Biophysical Research 114 930-936.

Bosma MM, Bernheim L, Leibowitz MD, Pfaffinger PJ \& Hille B 1990 Modulation of M current in frog sympathetic ganglion cells. In G Proteins and Signal Transduction, ch. 4, pp 43-59. Eds NM Nathanson \& TK Harden. New York, NY: The Rockefeller University Press.

Bouret SG, Draper SJ \& Simerly RB 2004 Trophic action of leptin on hypothalamic neurons that regulate feeding. Science 304 108-110.

Bowers CY 1999 Growth hormone-releasing peptides. In Handbook of Physiology, Section 7: The Endocrine System, pp 267-297. Ed JL Kostyo. Oxford, UK: Oxford University Press.

Bowers CY 2001 Unnatural growth hormone-releasing peptide begets natural ghrelin. Journal of Clinical Endocrinology and Metabolism 86 1464-1469.

Bowers CY, Chang J-K, Wu S, Linse KD, Hurley DL \& Veldhuis JD 2004 Biochemistry of the growth hormone releasing peptides, secretagogues and ghrelin. In Fat Loss, Wasting and Cachexia in Medicine, (In Press) Ed Montovani.

Brar BK, Jonassen AK, Egorina EM, Chen A, Negro A, Perrin MH, Mjos OD, Latchman DS, Lee KF \& Vale W 2004 Urocortin-II and urocortin-III are cardioprotective against ischemia reperfusion injury: an essential endogenous cardioprotective role for corticotropin releasing factor receptor type 2 in the murine heart. Endocrinology 145 24-35; discussion 21-23.

Brazeau P, Vale W, Burgus R, Ling N, Butcher M, Rivier J \& Guillemin R 1973 Hypothalamic polypeptide that inhibits the secretion of immunoreactive pituitary growth hormone. Science $\mathbf{1 7 9}$ 77-79.

Broberger C, Visser TJ, Kuhar MJ \& Hokfelt T 1999 Neuropeptide Y innervation and neuropeptide-Y-Y1-receptor-expressing neurons in the paraventricular hypothalamic nucleus of the mouse. Neuroendocrinology 70 295-305.

Broglio F, Arvat E, Benso A, Gottero C, Prodam F, Grottoli S, Papotti M, Muccioli G, van der Lely AJ, Deghenghi R et al. 2002 Endocrine activities of cortistatin-14 and its interaction with GHRH and ghrelin in humans. Journal of Clinical Endocrinology and Metabolism 87 3783-3790.

Broglio F, Gottero C, Prodam F, Gauna C, Muccioli G, Papotti M, Abribat T, van der Lely AJ \& Ghigo E 2004 Non-acylated ghrelin counteracts the metabolic but not the neuroendocrine response to acylated ghrelin in humans. Journal of Clinical Endocrinology and Metabolism 89 3062-3065.

Brooke MH 1989 Thyrotropin-releasing hormone in ALS. Are the results of clinical studies inconsistent? Annals of the New York Academy of Sciences $\mathbf{5 5 3}$ 422-430.

Brunson KL, Avishai-Eliner S, Hatalski CG \& Baram TZ 2001 Neurobiology of the stress response early in life: evolution of a concept and the role of corticotropin releasing hormone. Molecular Psychiatry 6 647-656.

Brunson KL, Grigoriadis DE, Lorang MT \& Baram TZ 2002 Corticotropin-releasing hormone $(\mathrm{CRH})$ downregulates the function of its receptor (CRF1) and induces CRF1 expression in hippocampal and cortical regions of the immature rat brain. Experimental Neurology 176 75-86.

Burgus R, Dunn TF, Desiderio D \& Guillemin R 1969 Molecular structure of the hypothalamic hypophysiotropic TRF factor of ovine 
origin: mass spectrometry demonstration of the PCA-His-Pro-NH2 sequence. Comptes Rendus hebdomadaires des Séances de l'Académie des Sciences 269 1870-1873.

Cesnjaj M, Krsmanovic LZ, Catt KJ \& Stojilkovic SS 1993 Autocrine induction of c-fos expression in GT1 neuronal cells by gonadotropin-releasing hormone. Endocrinology 133 3042-3045.

Cibelli G, Corsi P, Diana G, Vitiello F \& Thiel G 2001 Corticotropin-releasing factor triggers neurite outgrowth of a catecholaminergic immortalized neuron via cAMP and MAP kinase signalling pathways. European Journal of Neuroscience 13 1339-1348.

Coari G, Di Franco M, Iagnocco A, Di Novi MR, Mauceri MT \& Ciocci A 1995 Intra-articular somatostatin 14 reduces synovial thickness in rheumatoid arthritis: an ultrasonographic study. International Journal of Clinical Pharmacology Research 15 27-32.

Cummings SL, Young WS 3rd \& King JS 1994 Early development of cerebellar afferent systems that contain corticotropin-releasing factor. Journal of Comparative Neurology 350 534-549.

De Souza EB \& Nemeroff CB 1990 Corticotropin-Releasing Factor: Basic and Clinical Studies of a Neuropeptide, vol. 1. Eds EB De Souza \& CB Nemeroff. Boca Raton, FL: CRC Press.

Dees WL, Hiney JK, Sower SA, Yu WH \& McCann SM 1999 Localization of immunoreactive lamprey gonadotropin-releasing hormone in the rat brain. Peptides 20 1503-1511.

Ehrhart-Bornstein M, Hinson JP, Bornstein SR, Scherbaum WA \& Vinson GP 1998 Intraadrenal interactions in the regulation of adrenocortical steroidogenesis. Endocrine Reviews 19 101-143.

Elliott DE, Li J, Blum AM, Metwali A, Patel YC \& Weinstock JV 1999 SSTR2A is the dominant somatostatin receptor subtype expressed by inflammatory cells, is widely expressed and directly regulates T cell IFN-gamma release. European Journal of Immunology 29 2454-2463.

Fekete C, Legradi G, Mihaly E, Huang QH, Tatro JB, Rand WM, Emerson CH \& Lechan RM 2000 Alpha-melanocyte-stimulating hormone is contained in nerve terminals innervating thyrotropin-releasing hormone-synthesizing neurons in the hypothalamic paraventricular nucleus and prevents fasting-induced suppression of prothyrotropin-releasing hormone gene expression. Journal of Neuroscience 20 1550-1558.

Fulton JF, Ranson SW \& Frantz AM 1940 The Hypothalamus and Control Levels of Autonomic Functions. Baltimore, MD: Williams and Wilkins Co.

Gauna C, Meyler FM, Janssen JA, Delhanty PJ, Abribat T, van Koetsveld P, Hofland LJ, Broglio F, Ghigo E \& van der Lely AJ 2004 Administration of acylated ghrelin reduces insulin sensitivity, whereas the combination of acylated plus unacylated ghrelin strongly improves insulin sensitivity. Journal of Clinical Endocrinology and Metabolism 89 5035-5042.

Grino M, Young WS 3rd \& Burgunder JM 1989 Ontogeny of expression of the corticotropin-releasing factor gene in the hypothalamic paraventricular nucleus and of the proopiomelanocortin gene in rat pituitary. Endocrinology 124 60-68.

van Groeninghen JC, Kiesel L, Winkler D \& Zwirner M 1998 Effects of luteinising-hormone-releasing hormone on nervous-system tumours. Lancet 352 372-373.

Grundker C, Gunthert AR, Millar RP \& Emons G 2002 Expression of gonadotropin-releasing hormone II (GnRH-II) receptor in human endometrial and ovarian cancer cells and effects of GnRH-II on tumor cell proliferation. Journal of Clinical Endocrinology and Metabolism 87 1427-1430.

Guillemin R 1978 Peptides in the brain: the new endocrinology of the neuron. Science 202 390-402.

Guillemin R \& Rosenberg B 1955 Humoral hypothalamic control of anterior pituitary: a study with combined tissue cultures. Endocrinology 57 599-607.

Guillemin R, Brazeau P, Bohlen P, Esch F, Ling N \& Wehrenberg WB 1982 Growth hormone-releasing factor from a human pancreatic tumor that caused acromegaly. Science 218 585-587.
Guo F, Bakal K, Minokoshi Y \& Hollenberg AN 2004 Leptin signaling targets the thyrotropin-releasing hormone gene promoter in vivo. Endocrinology 145 2221-2227.

Hansson J \& Abrahamsson PA 2001 Neuroendocrine pathogenesis in adenocarcinoma of the prostate. Annals of Oncology 12 (Suppl 2) S145-S152.

Harris GW 1955 Neural Control of the Pituitary Gland, p. 298. London: E Arnold Publisher.

Heuer H, Schafer MK, O’Donnell D, Walker P \& Bauer K 2000 Expression of thyrotropin-releasing hormone receptor 2 (TRH-R2) in the central nervous system of rats. Journal of Comparative Neurology 428 319-336.

Huo L, Munzberg H, Nillni E \& Bjorbaek C 2004 Role of signal transducer and activator of transcription 3 in regulation of hypothalamic trh gene expression by leptin. Endocrinology 145 2516-2523.

Ipp E, Dobbs RE, Harris V, Arimura A, Vale W \& Unger RH 1977 The effects of gastrin, gastric inhibitory polypeptide, secretin, and the octapeptide of cholecystokinin upon immunoreactive somatostatin release by the perfused canine pancreas. Journal of Clinical Investigation 60 1216-1219.

Ito M 2001 Cerebellar long-term depression: characterization, signal transduction, and functional roles. Physiology Reviews 81 1143-1195.

Karalis K, Mastorakos G, Chrousos GP \& Tolis G 1994 Somatostatin analogs suppress the inflammatory reaction in vivo. Journal of Clinical Investigation 93 2000-2006.

Karalis K, Mastorakos G, Sano H, Wilder RL \& Chrousos GP 1995 Somatostatin may participate in the antiinflammatory actions of glucocorticoids. Endocrinology 136 4133-4138.

Kim MS, Small CJ, Russell SH, Morgan DG, Abbott CR, alAhmed SH, Hay DL, Ghatei MA, Smith DM \& Bloom SR 2002 Effects of melanocortin receptor ligands on thyrotropin-releasing hormone release: evidence for the differential roles of melanocortin 3 and 4 receptors. Journal of Neuroendocrinology 14 276-282.

Knobil E \& Hotchkiss J 1988 The menstrual cycle and its neuroendocrine control. In The Physiology of Reproduction, pp 1971-1994. Eds. E Knobil \& JD Neill. New York, NY: Raven Press Publications.

Kojima M, Hosoda H, Date Y, Nakazato M, Matsuo H \& Kangawa K 1999 Ghrelin is a growth-hormone-releasing acylated peptide from stomach. Nature 402 656-660.

Kovacs M, Zarandi M, Halmos G, Groot K \& Schally AV 1996 Effects of acute and chronic administration of a new potent antagonist of growth hormone-releasing hormone in rats: mechanisms of action. Endocrinology 137 5364-5369.

Kovacs M, Seprodi J, Koppan M, Horvath JE, Vincze B, Teplan I \& Flerko B 2002 Lamprey gonadotropin hormone-releasing hormone-III has no selective follicle-stimulating hormone-releasing effect in rats. Journal of Neuroendocrinology 14 647-655.

Krassas GE \& Kahaly GJ 1999 The role of octreoscan in thyroid eye disease. European Journal of Endocrinology 140 373-375.

Letsch M, Schally AV, Stangelberger A, Groot K \& Varga JL 2004 Antagonists of growth hormone-releasing hormone (GH-RH) enhance tumour growth inhibition induced by androgen deprivation in human MDA-Pca-2b prostate cancers. European Journal of Cancer 40 436-444.

Lieblich JM, Rogol AD, White BJ \& Rosen SW 1982 Syndrome of anosmia with hypogonadotropic hypogonadism (Kallmann syndrome): clinical and laboratory studies in 23 cases. American Journal of Medicine 73 506-519.

Liu J, Yu B, Neugebauer V, Grigoriadis DE, Rivier J, Vale WW, Shinnick-Gallagher P \& Gallagher JP 2004 Corticotropin-releasing factor and urocortin I modulate excitatory glutamatergic synaptic transmission. Journal of Neuroscience 24 4020-4029.

Lumpkin MD, McDonald JK, Samson WK \& McCann SM 1989 Destruction of the dorsal anterior hypothalamic region suppresses pulsatile release of follicle stimulating hormone but not luteinizing hormone. Neuroendocrinology 50 229-235. 
Marshall FHA 1936 Sexual periodicity and the causes which determine it. Philosophical Transactions of The Royal Society: Biological Sciences, Series B 226 423-456.

Mellon PL, Windle JJ, Goldsmith PC, Padula CA, Roberts JL \& Weiner RI 1990 Immortalization of hypothalamic GnRH neurons by genetically targeted tumorigenesis. Neuron $\mathbf{5}$ 1-10.

Millar RP 2003 GnRH II and type II GnRH receptors. Trends in Endocrinology and Metabolism 14 35-43.

Millar R, Lowe S, Conklin D, Pawson A, Maudsley S, Troskie B, Ott T, Millar M, Lincoln G, Sellar R et al. 2001 A novel mammalian receptor for the evolutionarily conserved type II GnRH. PNAS $\mathbf{9 8}$ 9636-9641.

Moretti RM, Montagnani Marelli M, Van Groeninghen JC \& Limonta P 2002 Locally expressed LHRH receptors mediate the oncostatic and antimetastatic activity of LHRH agonists on melanoma cells. Journal of Clinical Endocrinology and Metabolism $\mathbf{8 7}$ 3791-3797.

Mosca A, Dogliotti L, Berruti A, Lamberts SW \& Hofland LJ 2004 Somatostatin receptors: from basic science to clinical approach.Unlabeled somatostatin analogs-1: prostate cancer. Digestive and Liver Diseases 36 (Suppl 1) S60-S67.

Muller MB, Zimmermann S, Sillaber I, Hagemeyer TP, Deussing JM, Timpl P, Kormann MS, Droste SK, Kuhn R, Reul JM et al. 2003 Limbic corticotropin-releasing hormone receptor 1 mediates anxiety-related behavior and hormonal adaptation to stress. Nature Neuroscience 6 1100-1107.

Nair RM, Barrett JF, Bowers CY \& Schally AV 1970 Structure of porcine thyrotropin releasing hormone. Biochemistry 9 1103-1106.

Neill JD, Duck LW, Sellers JC \& Musgrove LC 2001 A gonadotropin-releasing hormone $(\mathrm{GnRH})$ receptor specific for GnRH II in primates. Biochemical and Biophysical Research Communications 282 1012-1018.

Neill JD, Musgrove LC \& Duck LW 2004 New GnRH receptors: function and relative role. Trends in Endocrinology and Metabolism 15 383-392.

Nillni EA \& Sevarino KA 1999 The biology of pro-thyrotropinreleasing hormone-derived peptides. Endocrine Reviews 20 599-648.

O'Byrne KJ, Schally AV, Thomas A, Carney DN \& Steward WP 2001 Somatostatin, its receptors and analogs, in lung cancer. Chemotherapy 47 (Suppl 2) 78-108.

Owens MJ \& Nemeroff CB 1999 Corticotropin-releasing factor antagonists in affective disorders. Expert Opinion on Investigational Drugs 8 1849-1858.

Padmanabhan V \& McNeilly AS 2001 Is there an FSH-releasing factor? Reproduction 121 21-30.

Palkovits M, Leranth C, Gorcs T \& Young WS 3rd 1987 Corticotropin-releasing factor in the olivocerebellar tract of rats: demonstration by light- and electron-microscopic immunohistochemistry and in situ hybridization histochemistry. PNAS 84 3911-3915.

Pandya N, DeMott-Friberg R, Bowers CY, Barkan AL \& Jaffe CA 1998 Growth hormone (GH)-releasing peptide-6 requires endogenous hypothalamic GH-releasing hormone for maximal GH stimulation. Journal of Clinical Endocrinology and Metabolism $\mathbf{8 3}$ 1186-1189.

Patchett AA, Nargund RP, Tata JR, Chen MH, Barakat KJ, Johnston DB, Cheng K, Chan WW, Butler Bi, Hickey G et al. 1995 Design and biological activities of L-163,191 (MK-0677): a potent, orally active growth hormone secretagogue. PNAS 92 7001-7005.

Pinto S, Roseberry AG, Liu H, Diano S, Shanabrough M, Cai X, Friedman JM \& Horvath TL 2004 Rapid rewiring of arcuate nucleus feeding circuits by leptin. Science 304 110-115.

Rasmussen DD, Gambacciani M, Swartz W, Tueros VS \& Yen SS 1989 Pulsatile gonadotropin-releasing hormone release from the human mediobasal hypothalamus in vitro: opiate receptor-mediated suppression. Neuroendocrinology 49 150-156.
Raulf PJ, Hoyer C \& Bruns C 1994 Differential expression of five somatostatin receptor subtypes, SSTR 1-5 in the CNS and peripheral tissue. Digestion 55 46-53.

Reichlin S 1960 Thyroid function, body temperature regulation and growth in rats with hypothalamic lesions. Endocrinology 66 340-354.

Reubi JC 2003 Peptide receptors as molecular targets for cancer diagnosis and therapy. Endocrine Reviews 24 389-427.

Rissman EF, Li X, King JA \& Millar RP 1997 Behavioral regulation of gonadotropin-releasing hormone production. Brain Research Bulletin 44 459-464.

Rivier C, Rivier J \& Vale W 1978 Chronic effects of [D-Trp6-Pro9-NEt]luteinizing hormone-releasing factor on reproductive processes in the female rat. Endocrinology 103 2299-2305.

Rugarli EI, Di Schiavi E, Hilliard MA, Arbucci S, Ghezzi C, Facciolli A, Coppola G, Ballabio A \& Bazzicalupo P 2002 The Kallmann syndrome gene homolog in C. elegans is involved in epidermal morphogenesis and neurite branching. Development 129 1283-1294.

Saffran M \& Schally AV 1955 The release of corticotrophin by anterior pituitary tissue in vitro. Canadian Journal of Medical Sciences 33 408-415.

Saffran M \& Schally AV 1956 Effect of histamine, hog vasopressin, and corticotropin-releasing factor (CRF) on ACTH release in vitro. Proceedings of the Society for Experimental Biology and Medicine 92 636-637.

Scharrer B 1978 Peptidergic neurons: facts and trends. General and Comparative Endocrinology 34 50-62.

Schulz S, Helmholz T, Schmitt J, Franke K, Otto HJ \& Weise W 2002 True positive somatostatin receptor scintigraphy in primary breast cancer correlates with expression of sst $2 \mathrm{~A}$ and sst5. Breast Cancer Research and Treatment 72 221-226.

Schwarting GA, Raitcheva D, Bless EP, Ackerman SL \& Tobet S 2004 Netrin 1-mediated chemoattraction regulates the migratory pathway of LHRH neurons. European Journal of Neuroscience 19 $11-20$.

Seres J, Bornstein SR, Seres P, Willenberg HS, Schulte KM, Scherbaum WA \& Ehrhart-Bornstein M 2004 Corticotropinreleasing hormone system in human adipose tissue. Journal of Clinical Endocrinology and Metabolism 89 965-970.

Silverman AJ, Jhamandas J \& Renaud LP 1987 Localization of luteinizing hormone-releasing hormone (LHRH) neurons that project to the median eminence. Journal of Neuroscience 7 2312-2319.

Starling EH 1905a The Croonian Lectures on the chemical correlation of the functions of the body. Lancet 2 339-341, 423-425, 501-503, $578-583$.

Starling EH $1905 b$ The chemical control of the functions of the body: Croonian Lecture \#1 (June 20 1905). Lancet 2 339-341.

Szepeshazi K, Schally AV, Groot K, Armatis P, Hebert F \& Halmos G $2000 a$ Antagonists of growth hormone-releasing hormone (GH-RH) inhibit in vivo proliferation of experimental pancreatic cancers and decrease IGF-II levels in tumours. European Journal of Cancer 36 128-136.

Szepeshazi K, Schally AV, Groot K, Armatis P, Halmos G, Herbert F, Szende B, Varga JL \& Zarandi M 2000 b Antagonists of growth hormone-releasing hormone (GH-RH) inhibit IGF-II production and growth of HT-29 human colon cancers. British Journal of Cancer 82 1724-1731.

Takaya K, Ariyasu H, Kanamoto N, Iwakura H, Yoshimoto A, Harada M, Mori K, Komatsu Y, Usui T, Shimatsu A et al. 2000 Ghrelin strongly stimulates growth hormone release in humans. Journal of Clinical Endocrinology and Metabolism 85 4908-4911.

Tang X, Yano T, Osuga Y, Matsumi H, Yano N, Xu J, Wada O, Koga K, Kugu K, Tsutsumi O et al. 2002 Cellular mechanisms of growth inhibition of human epithelial ovarian cancer cell line by LH-releasing hormone antagonist Cetrorelix. Journal of Clinical Endocrinology and Metabolism 87 3721-3727. 
Tian JB \& Bishop GA 2003 Frequency-dependent expression of corticotropin releasing factor in the rat's cerebellum. Neuroscience 121 363-377.

Tobet SA, Chickering TW, King JC, Stopa EG, Kim K, Kuo-Leblank V \& Schwarting GA 1996 Expression of gamma-aminobutyric acid and gonadotropin-releasing hormone during neuronal migration through the olfactory system. Endocrinology 137 5415-5420.

Vale W, Spiess J, Rivier C \& Rivier J 1981 Characterization of a 41-residue ovine hypothalamic peptide that stimulates secretion of corticotropin and beta-endorphin. Science 213 1394-1397.

Varga JL, Schally AV, Horvath JE, Kovacs M, Halmos G, Groot K, Toller GL, Rekasi Z \& Zarandi M 2004 Increased activity of antagonists of growth hormone-releasing hormone substituted at positions 8, 9, and 10. PNAS 101 1708-1713.

Veldhuis JD 2003 A tripeptidyl ensemble perspective of interactive control of growth hormone secretion. Hormone Research 60 (Suppl 1) 86-101.

Weckbecker G, Lewis I, Albert R, Schmid HA, Hoyer D \& Bruns C 2003 Opportunities in somatostatin research: biological, chemical and therapeutic aspects. Nature Reviews Drug Discovery 2 999-1017.

Wehrenberg WB, Ling N, Bohlen P, Esch F, Brazeau P \& Guillemin R 1982 Physiological roles of somatocrinin and somatostatin in the regulation of growth hormone secretion. Biochemical and Biophysical Research Communications 109 562-567.

Weinstock JV \& Elliott D 2000 The somatostatin immunoregulatory circuit present at sites of chronic inflammation. European Journal of Endocrinology 143 (Suppl 1) S15-S19.

White RB, Eisen JA, Kasten TL \& Fernald RD 1998 Second gene for gonadotropin-releasing hormone in humans. PNAS 95 305-309.

Wilber JF \& Porter JC 1970 Thyrotropin and growth hormone releasing activity in hypophysial portal blood. Endocrinology 87 807-811.

Wirsig-Wiechmann CR 2001 Function of gonadotropin-releasing hormone in olfaction. Keio Journal of Medicine 50 81-85.

Wittmann G, Liposits Z, Lechan RM \& Fekete C 2004a Medullary adrenergic neurons contribute to the cocaine- and amphetamine- regulated transcript-immunoreactive innervation of thyrotropinreleasing hormone synthesizing neurons in the hypothalamic paraventricular nucleus. Brain Research 1006 1-7.

Wittmann G, Sarkar S, Hrabovszky E, Liposits Z, Lechan RM \& Fekete C 2004b Galanin- but not galanin-like peptide-containing axon terminals innervate hypophysiotropic TRH-synthesizing neurons in the hypothalamic paraventricular nucleus. Brain Research 1002 43-50.

Wray S, Grant P \& Gainer H 1989 Evidence that cells expressing luteinizing hormone-releasing hormone mRNA in the mouse are derived from progenitor cells in the olfactory placode. PNAS $\mathbf{8 6}$ 8132-8136.

Yen SS 2004 Neuroendocrinology of Reproduction. In Yen and Jaffe's Reproductive Endocrinology, 5th Edition, pp 1-73. Eds JF Strauss \& RL Barbieri. Philedelphia, PA: Elsevier Science Publication.

Yen SS \& Jaffe RB 2004 In Yen and Jaffe's Reproductive Endocrinology. 5th Edition. Eds JF Strauss \& RL Barbieri. Philedelphia, PA: Elsevier Science Publication.

Yu WH, Karanth S, Mastronardi CA, Sealfon S, Dean C, Dees WL \& McCann SM 2002 Lamprey GnRH-III acts on its putative receptor via nitric oxide to release follicle-stimulating hormone specifically. Experimental Biology and Medicine 227 786-793.

Zapata PD, Ropero RM, Valencia AM, Buscail L, Lopez JI, Martin-Orozco RM, Prieto JC, Angulo J, Susini C, Lopez-Ruiz P et al. 2002 Autocrine regulation of human prostate carcinoma cell proliferation by somatostatin through the modulation of the SH2 domain containing protein tyrosine phosphatase (SHP)-1. Journal of Clinical Endocrinology and Metabolism 87 915-926.

Zorrilla EP \& Koob GF 2004 The therapeutic potential of $\mathrm{CRF}_{1}$ antagonists for anxiety. Expert Opinion on Investigational Drugs $\mathbf{1 3}$ 799-828.

Received 29 June 2004

Accepted 26 August 2004 